\title{
FINDING OF NO SIGNIFICANT IMPACT
}

\author{
USE OF EXISTING BORROW AREAS \\ HANFORD SITE, RICHLAND, WASHINGTON \\ OCTOBER 2001
}


This page intentionally left blank. 
AGENCY: U.S. Department of Energy

ACTION: Finding of No Significant Impact

SUMMARY: The U.S. Department of Energy (DOE) has prepared an Environmental Assessment (EA), DOE/EA-1403, to assess environmental impacts associated with the use of existing borrow sites on the Hanford Site, Richland, Washington.' Based on the analysis in the $\mathrm{EA}$, and considering public comments, DOE has determined that the preposed action is not a major federal action significantly affecting the quality of the human environment within the meaning of the National Environmental Policy Act of 1969 (NEPA), 42 U.S.C. 4321, et seq. Therefore, the preparation of an Environmental Impact Statement (EIS) is not required.

ADDRESSES AND FURTHER INFORMATION: Single copies of the EA and further information about the proposed action are available from:

U.S. Department of Energy

Richland Operations Office

Shannon M. Ortiz, Document Manager

Office of Site Services

P.O. Box 550, MS A2-15

Richland, Washington 99352

Phone: (509) 373-0908

e-mail: Shannon M Ortiz@rl.gov

For further information regarding the DOE NEPA process, contact:

U.S. Department of Energy

Richland Operations Office

P. F. X. Dunigan, Jr., NEPA Compliance Officer

P.O. Box 550, MS A5-58

Richland, Washington 99352

Phone: (509) 376-6667)

e-mail: $\underline{\text { Paul F Jr Dunigan@rl.gov }}$

Ms. Carol M. Borgstrom, Director

Office of NEPA Oversight

U.S. Department of Energy

1000 Independence Avenue, S.W.

Washington, D.C. 2085

Phone: (202-586-4600)

e-mail: Carol.Borgstrom@hq.doe.gov

PURPOSE AND NEED: The U.S. Department of Energy needs to identify and operate onsite locations for a continued supply of raw aggregate for new facility construction, maintenance of existing facilities and transportation corridors, and fill and capping material for remediation and other sites. 
BACKGROUND: Historically, mineral resources extracted on the Hanford Site have been used to make concrete, construct roads, cap material for closing waste sites, and general construction. Associated land-use commitments in general, and borrow sites specifically, have been and continue to be addressed when considering activities on the Hanford Site.

Most recently, land use on the Hanford Site has been addressed in DOE/EIS-0222-F, Final Hanford Comprehensive Land-Use Plan Environmental Impact Statement In the Record of Decision, DOE made a commitment to perform a NEPA analysis addressing gravel quarries. This EA honors that commitment. Ten-year volume projections of borrow needs have been estimated in Fiscal Year 2001; [approximately 7,600,000 cubic meters (10,000,000 cubic yards) over the next 10 years]. Further, an industrial mineral resources management plan is being prepared that will include a framework for the planning, operations, and closure/restoration of borrow pits and quarries. This plan is required to be developed as one of a series of resource management plans needed to implement DOE/EIS-0222-F.

PROPOSED ACTION: The DOE proposes to obtain borrow materials from existing active borrow pits and quarries on the Hanford Site. The total volume of materials to be recovered over a 10 -year period is estimated to be approximately $7.600,000$ cubic meters $(10,000,000$ cubic yards).

The proposed action would include ensuring adequate access is provided to the borrow locations. Existing roads might be upgraded, as necessary, to enhance egress. Appropriate utilities would be provided, and might include portable generators or extension of power lines for lighting, installation of trailers for personnel, and portable toilets.

Conventional industrial equipment would be used during operations to recover the borrow material. For example, a power shovel or a front-end loader would excavate materials. New or modified equipment and facilities would be provided at the specific locations to provide for crushing, screening, size classification, washing, handling, and stockpiling. Truck loading stations would be provided.

Depending on the nature of specific borrow materials at individual locations, select sites might be expanded. For analysis, it is assumed that of the total disturbed surface area (i.e., 3 square kilometers or 1.2 square miles), expansion could result in an additional surface area disturbance of 10 percent (approximately 0.3 square kilometers [0.12 square miles]). The resulting volume of additional borrow material available from expansion would be approximately $1,500,000$ cubic meters $(2,000,000$ cubic yards).

As necessary, activities supporting expansion would be conducted. Such activities might include temporary site improvements, such as grading, adding or amending soils, seeding, planting, and other actions, which might be implemented selectively at borrow areas to help reduce erosion, run-off, and dust emissions. Offset mitigation activities for habitat destruction would be performed as necessary. These activities would be consistent with resource management plans developed for the Hanford Site, including DOE/RL-96-32 (Hanford Site Biological Resources Management Plan), DOE/RL-96-88 (Hanford Site Biological Resources Mitigation Strategy), and DOE/RL-98-10 (Hanford Cultural Resources Management Plan), as well as other plans under preparation (e.g., aesthetic and visual resources). 
ALTERNATIVES CONSIDERED: The EA discussed a variety of alternatives as well as the No-Action Alternative.

No-Action Alternative. Under the No-Action Alternative, continued excavation of borrow materials would be conducted for site maintenance activities and remediation under Comprehensive Environmental Response, Compensation, and Liability Act (CERCLA) of 1980 RODs.

Alternatives. Alternatives addressed in the EA included: procurement of borrow material from offsite commercial entity exclusively, supplementing existing onsite sources by establishing new onsite borrow areas, and supplementing existing onsite sources by procurement of offsite materials.

ENVIRONMENTAL IMPACTS: Activities associated with excavation and transportation of borrow materials would not result in any significant environmental impacts.

Routine Operations No radiological or toxicological exposure to personnel or the general public is expected to occur as a result of routine excavation operations, either loading or offloading activities. No significant impacts to air quality, water quality, land use, ecological or cultural and aesthetic and visual resources would occur. Impacts to shrub-steppe habitat would be mitigated as necessary consistent with the Hanford Site Biological Resources Management Plan and the Hanford Site Biological Resources Mitigation Strategy. No unique hazards that would result in increased risk to the worker or public during onsite transportation of borrow materials were identified.

Accident Scenarios Accident consequences have been considered for the proposed action. Postulated accidents associated with the excavation of borrow materials on the Hanford Site have been considered, and are believed to be bounded by those potential events associated with transportation accidents. It is expected that borrow materials would not contribute disproportionate risks to ongoing intra-site transport.

Socioeconomic Impacts The proposed action would not result in significant socioeconomic impacts. It would be expected that the existing Hanford Site workforce would provide the bulk of necessary personnel to support excavation and transportation of borrow materials. There would be no discernible impact to employment levels within Benton and Franklin counties.

Environmental Justice Executive Order 12898, Federal Actions to Address Environmental Justice in Minority Populations and Low-Income Populations, directs federal agencies to identify and address, as appropriate, disproportionately high and adverse human health or environmental effects of their programs and activities on minority and low-income populations. The analysis in this EA indicates that there would be minimal impacts to both the offsite population and potential workforce during recovery and transportation of borrow materials, under both routine and accident conditions. Therefore, it is not expected that there would be any disproportionately high and adverse impacts to any minority or low-income populations.

Cumulative Impacts Cumulative environmental impacts were considered but no significant cumulative impacts are expected from implementation of the proposed action. 
DETERMINATION: Based on the analysis in the EA, and after considering the comments received, I conclude that the proposed action for use of existing borrow sites on the Hanford Site does not constitute a major federal action significantly affecting the quality of the human environment within the meaning of NEPA. Therefore, an EIS is not required.

Issued at Richland, Washington, this 10 th day of October, 2001.

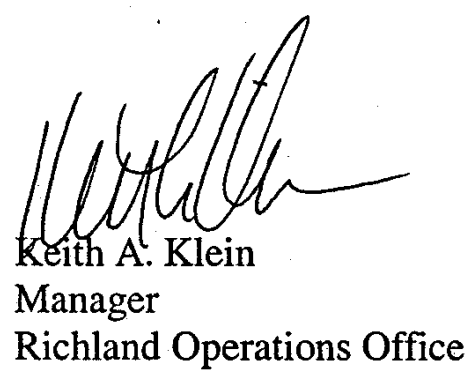

